\title{
Hubungan Trombositopenia, Parasitemia serta Mediator Pro dan Anti Inflamasi pada Infeksi Malaria, Timika 2010
}

\author{
Association Between Trombocytopenia, Parasitemia, Pro and Anti-Inflamatory in Malaria Infection, \\ Timika 2010
}

\author{
Armedy Ronny Hasugian*1, Heri Wibowo ${ }^{2}$, dan Emiliana Tjitra ${ }^{1}$ \\ ${ }^{1}$ Pusat Penelitian dan Pengembangan Sumber Daya dan Pelayanan Kesehatan Badan Penelitian dan \\ Pengembangan Kesehatan, Kementerian Kesehatan RI, Jl. Percetakan Negara No. 29 Jakarta, Indonesia \\ ${ }^{2}$ Departmen Parasitologi, Fakultas Kedokteran, Universitas Indonesia, J1. Salemba Raya No. 6, Jakarta \\ Pusat 10430 , Indonesia \\ *Korespondensi Penulis: medyrh@gmail.com
}

Submitted: 16-07-2018; Revised: 13-09-2018; Accepted: 17-09-2018

DOI: https://doi.org/10.22435/mpk.v28i3.110

\begin{abstract}
Abstrak
Trombositopenia berhubungan dengan tingkat keparahan malaria. Parasitemia dan sistem kekebalan tubuh memiliki peran penting pada manifestasi infeksi malaria termasuk trombositopenia. Oleh karenanya penelitian ini bertujuan untuk menentukan hubungan antara trombositopenia, parasitemia, dan sitokin pada Plasmodium falciparum dan P.vivax. Desain studi adalah potong lintang, dilaksanakan di Rumah Sakit Mitra Masyarakat, Timika, Papua pada tahun 2010. Subjek penelitian adalah semua kelompok umur dengan malaria tanpa komplikasi. Pada perekrutan, karakteristik subjek akan dicatat, parasitemia dihitung dengan mikroskop, trombosit diukur dengan Hematology analyzer (Sysmex) dan sitokin diukur dengan Multiplex Flow Cytometry Assay (Luminex). Trombositopenia didefinisikan jika jumlah trombosit $<150.000 \mathrm{~mm}^{3}$. Sitokin yang dipaparkan adalah rasio TNFa/IL10, IFNy/IL10, dan IL12/IL10. Hubungan trombositopenia, parasitemia, dan sitokin ditentukan dengan analisis multivariat logistik. Sebanyak 76 subjek malaria mono-infeksi direkrut, $51,3 \%$ terinfeksi $P$. falciparum dan $48,7 \% P$. vivax. Rata-rata umur

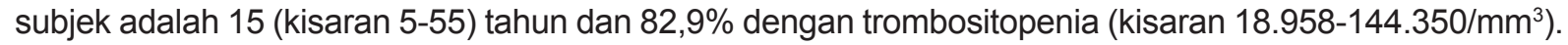
Rerata geometrik parasitemia adalah $3.393(43-412.503) / \mathrm{mm}^{3}$, sedangkan median masing-masing rasio TNFa/IL10, IFNy/IL10 dan IL12/IL10 yaitu 1,05, 0,99; dan 0,99. Analisis bivariat menunjukkan bahwa trombositopenia berhubungan dengan rendahnya tingkat TNFa/IL10 $(p=0,015)$ dan tingginya rasio IL12/ IL10 ( $p=0,020)$. Hasil analisis multivariat menunjukkan adanya hubungan antara trombositopenia dan rasio TNFa/IL10 rendah $(<1,05)$ dengan OR: 7,33 (95\% Cl: 1,5-35,8), p = 0,014. Trombositopenia dikaitkan dengan rendahnya rasio TNFa/ IL10 pada pasien infeksi dari $P$. falciparum dan $P$. vivax tanpa komplikasi. Kata Kunci: trombositopenia; parasitemia; sitokin; malaria; infeksi
\end{abstract}

\begin{abstract}
Thrombocytopenia is related with severity of malaria. Parasitaemia and immune system have important roles for the reactions that occur in malaria infections including thrombocytopenia. Therefore, we conducted a study to determine the association between thrombocytopenia, parasitaemia and cytokines in Plasmodium falciparum and P.vivax. This was a cross-sectional and hospital based study at Mitra Masyarakat Hospital, Timika, Papua, in 2010. Subjects were all age groups with uncomplicated malaria. On admission, characteristics subjects were recorded, parasitaemia was calculated by using microscope, platelets were measured by Hematology analyzer (Sysmex), and cytokines were measured by Multiplex Flow Cytometry Assay (Luminex). Thrombocytopenia was defined if platelet count $<150,000 / \mathrm{mm}^{3}$. Cytokines were presented in ratio of TNFa/IL10, IFNY/IL10, and IL12/IL10. The association thrombocytopenia,
\end{abstract}


parasitaemia and cytokines were determined by logistic multivariate analysis. A total 76 subjects were recruited, $51.3 \%$ infected with $P$. falciparum and $48.7 \%$ infected with $P$. vivax infection. The mean age of subjects was 15 (range 5 - 55) years and 82.9\% with thrombocytopenia (platelet range 18,958-144,350/ $\mathrm{mm}^{3}$ ). The geometric mean of parasitemia was 3,393 $(43-412,503) / \mathrm{mm}^{3}$, while the median of ratios TNFa/IL10, IFN Y/IL10 and IL12/IL10 were 1.05; 0.99; and 0.99, respectively. Bivariate analysis showed that thrombocytopenia was associated with low level of TNFa/IL10 $(p=0.015)$ and IL12/IL10 (0.020). The multivariate analysis data also showed a relationship between thrombocytopenia and ratio of TNFa/IL10 with adjusted OR of 7.33 (95\% Cl: 1.5-35.8), $p=0.014$. Thrombocytopenia is associated with low ratio of TNFa/IL10 in patients with uncomplicated infection of $P$. falciparum and P.vivax.

Keywords: thrombocytopenia; parasitemia; cytokine; malaria; infection

\section{PENDAHULUAN}

Trombositopenia adalah jumlah platelet $<150.000 / \mathrm{mm}^{3}$ di dalam tubuh, yang mana dalam keadaan $<10.000 / \mathrm{mm}^{3}$ dapat menyebabkan perdarahan spontan mucocutaneous dan mengancam jiwa. $^{1}$ Kejadian trombositopenia disebabkan adanya proses peningkatan penghancuran platelet ataupun penurunan produksi platelet. Proses ini dipicu oleh berbagai faktor seperti genetik, infeksi, keganasan, radiasi, dan lainnya. ${ }^{1,2}$ Salah satu infeksi yang dapat menyebabkan trombositopenia adalah malaria. Mekanisme terjadinya trombositopenia pada malaria sangat bervariasi diantaranya disebabkan gangguan koagulasi, splenomegali, hingga reaksi imun. ${ }^{2}$

Infeksi malaria menimbulkan berbagai manifestasi klinis dan laboratoris yang dipicu oleh adanya reaksi imun, diantaranya pelepasan sistem imun seluler yaitu sitokin pro inflamasi dan anti inflamasi. Fungsi sistem imun pada infeksi malaria umumnya berkaitan dengan proses pembersihan atau eradikasi plasmodium/parasitemia dari dalam tubuh. ${ }^{3}$ Sitokin yang sering berperan pada infeksi malaria diantaranya adalah TNF $\alpha$, IFN $\gamma$, IL12 sebagai proinflamasi serta IL10 sebagai antiinflamasi. ${ }^{4}$ Namun TNFo, IFN $\gamma$, IL12 cenderung memberi efek kerusakan pada jaringan disekitar infeksi terjadi. Peran IL10 dalam hal ini adalah sebagai regulator yang mengendalikan produksi dan kerja TNF $\alpha$, IFN $\gamma$, IL12.,

Hasil penelitian di Kenya dan Pakistan menunjukkan bahwa trombositopenia berhubungan dengan beberapa sitokin seperti TNF $\alpha$, IL6, dan IL10. ${ }^{6,7}$ Penelitian trombositopenia pada $P$. vivax, menunjukkan terjadi peningkatan kadar IL10 sebanyak 3 kali lipat pada penderita dibandingkan dengan orang sehat. ${ }^{7}$ Sementara pada $P$. falciparum, perubahan sitokin meningkatkan peluang terjadinya malaria dengan komplikasi. ${ }^{8}$ Peningkatan dan perubahan keseimbangan sitokin pro dan anti inflamasi dalam tubuh terinfeksi akan meningkatkan kemungkinan berbagai manifestasi klinis dan laboratoris yang tentunya dapat membahayakan penderita diakibatkan adanya kerusakan jaringan/sel. Hal ini menegaskan bahwa trombositopenia dapat menjadi salah satu penanda yang dapat digunakan sebagai penilai berat ringannya infeksi malaria.

Oleh sebab itu penelitian ini dilakukan bertujuan untuk menilai hubungan trombositopenia dengan parasitemia dan sitokin pada pasien malaria tanpa komplikasi. Sitokin pro inflamasi TNF $\alpha$, IFN $\gamma$, IL12 dan IL10 sebagai sitokin anti inflamasi dipilih karena merupakan sitokin yang sering dilaporkan berkaitan dengan infeksi malaria. ${ }^{9,10}$

\section{METODE}

Penelitian ini merupakan penelitian observasional laboratoris dengan desain potong lintang yang dilakukan di Rumah Sakit Mitra Masyarakat (RSMM), Timika, Papua pada MeiDesember tahun 2010. Artikel ini merupakan bagian dari penelitian utama yang sudah dipublikasikan yang berjudul "Hubungan kadar hemoglobin dengan respon sitokin proinflamasi dan antiinflamasi pada penderita infeksi $P$. falciparum dan $P$. vivax". ${ }^{11}$ Populasi penelitian ini adalah semua penderita malaria falsiparum dan vivaks yang berobat ke RSMM. Subjek malaria yang direkrut adalah monoinfeksi malaria $P$. falciparum dan P.vivax, umur $>2$ tahun dengan manifestasi klinis malaria dan sukarela mengikuti penelitian. Sementara pasien malaria berat dan penyakit kronis lainnya, gangguan gizi berat, wanita hamil, dan kadar hemoglobin $<5$ gr\% tidak direkrut. Jumlah subjek sesuai dengan penelitian utama yang sudah dipublikasikan yaitu 76 orang. ${ }^{11}$

Pada perekrutan $3 \mathrm{ml}$ sampel diambil dari vena mediana cubiti untuk sediaan darah malaria tebal dan tipis, hematologi dan sitokin. Pemeriksaan mikroskopis menggunakan pewarnaan Giemsa 
5\%. Perhitungan parasitemia dilakukan per 200 leukosit. Pemeriksaan hematologi rutin dilakukan dengan mesin Hematology analyzer (Sysmex) yang mengeluarkan hasil hematologi rutin termasuk trombosit/platelet. Pengukuran sitokin dilakukan dengan prosedur dari Bio-Plex ProTM Assay menggunakan mesin Multiplex Flow Cytometry Assay (luminex 200). Supernatan yang didapatkan dari whole blood yang dikultur dengan media kultur RPMI 1.640, glutamax, streptomycin dulfstr dslt 1 gr, dan penisilin beku dalam aquabidest. ${ }^{11}$ Pengukuran tersebut dilakukan di Laboratorium Imunologi, Badan Penelitian dan Pengembangan Kesehatan pada tahun 2010. Hasil sitokin yang didapatkan dan dianalisis adalah hasil pengurangan sitokin TNF $\alpha$, IFN $\gamma$, IL12 yang distimulasi dan tidak distimulasi oleh Phytohaemagglutinin (PHA), sementara sitokin IL10 yang dinilai adalah kadar sitokin yang tidak distimulasi. ${ }^{11}$

Data karakteristik demografi subjek, hasil pemeriksaan laboratorium dicatat pada case report form (CRF). Jenis kelamin dan jenis spesies termasuk sebagai data trombosit dikelompokkan menjadi kelompok trombositopenia $(<150.000 /$ $\left.\mathrm{mm}^{3}\right)$ dan non-trombositopenia $\left(\geq 150.000 / \mathrm{mm}^{3}\right)$. Umur, lama menderita sakit terakhir, demam, parasitemia, serta nilai rasio sitokin pro inflamasi terhadap anti inflamasi; TNF $\alpha /$ IL10, IFN $\gamma /$ IL10, dan IL12/IL10 yang merupakan data numerik, dikelompokkan berdasarkan distribusi normalitas data. Analisis bivariat (cross tabulation), multivariat (logistic multivariat) dilakukan untuk menilai hubungan trombositopenia dengan variabel tersebut di atas. Analisis tambahan (uji Pearson atau Spearman) dilakukan untuk menilai korelasi platelet, parasitemia, sitokin TNF $\alpha$, IFN $\gamma$, IL12 dan IL10. Analisis dilakukan dengan SPSS versi 16. Etik penelitian didapatkan dari Komisi Etik Penelitian dan Kesehatan, Badan Litbang Kesehatan No. LB.03.02/KE/3059/2010.

\section{HASIL}

Total 76 subyek malaria mono-infeksi, 51,3\% subyek terinfeksi P. falciparum dan 48,7\% P. vivax direkrut pada penelitian ini, $59,2 \%$ adalah laki-laki. Rerata umur subjek penelitian adalah 15 (kisaran 5-55) tahun dan hanya 40,8\%. Subjek dengan demam $\left(37,5^{\circ} \mathrm{C}\right)$ dengan median lama sakit selama 3 (1-7) hari. Sebanyak 82,9\% subyek menunjukkan trombositopenia $\left(<150.000 / \mathrm{mm}^{3}\right)$, kisaran platelet yang diukur 18.958-144.350/ $\mathrm{mm}^{3}$. Rerata geometrik trombosit pada infeksi $P$. falciparum dan $P$. vivax adalah 69.182 (kisaran 18.958-196.811)/mm $\mathrm{mm}^{3}$ dan 118.907 (51.021$341.123) / \mathrm{mm}^{3}$. Rerata geometrik parasitemia adalah 3.393 (kisaran 43-412.503) $/ \mathrm{mm}^{3}$, dengan P. falciparum $8.371 \quad(395-412.503) / \mathrm{mm}^{3}$ dan P.vivax $1.312(43-41.772) / \mathrm{mm}^{3}$. Tidak ditemukan manifestasi klinis malaria berat berdasarkan hasil pemeriksaan parasitemia. Median dari rasio TNF $\alpha /$ IL10, IFN $\gamma /$ IL10, dan IL12/IL10 sesuai dengan hasil penelitian yang sudah dipublikasikan yaitu berturut-turut 1,05 (kisaran 0,81-1,20); $0,99 \quad(0,57-1,05) ; \quad 0,99 \quad(0,86-1,04) .{ }^{11} \quad$ Data dikelompokkan menjadi variabel trombositopenia $\left(<150.000, \geq 150.000 / \mathrm{mm}^{3}\right)$, demam $\left(<37,5^{\circ} \mathrm{C}\right.$, $\geq 37,5^{\circ} \mathrm{C}$ ), lama sakit ( $<3$ hari, $\geq 3$ hari), parasitemia $\left(<3.393 / \mathrm{mm}^{3}, \geq 3.393 / \mathrm{mm}^{3}\right)$, rasio sitokin $\mathrm{TNF} \alpha /$ IL10 $(<1,05, \geq 1,05), \quad$ IFN $\gamma / \operatorname{IL} 10(<0,99, \geq 0,99)$, dan IL12/IL10 $(<0,99, \geq 0,99)$.

Hasil analisis uji korelasi dipaparkan pada Tabel 1, didapatkan hubungan yang bermakna $(p<0,05)$ antara platelet dengan parasitemia, sitokin TNF $\alpha$ dan IL10 yang dinilai (nilai p sig). Uji korelasi platelet dengan parasitemiia dan IL10 menunjukkan hubungan terbalik. Hasil uji korelasi juga menunjukkan bahwa sitokin IFN $\gamma$ dan IL12 tidak mempunyai hubungan bermakna dengan platelet.

Hasil analisis bivariat dipaparkan pada Tabel 2 yang menunjukkan rasio TNF $\alpha /$ IL10 dan IL12/IL10 mempunyai hubungan bermakna $(\mathrm{p}<0,05)$ dengan trombositopenia trombosit $(<150.000 / \mathrm{mm} 3)$. Hasil bivariat rasio IFN $\gamma /$ IL10 menunjukkan tidak adanya hubungan yang bermakna dengan trombositopenia. Sementara hasil lainnya seperti umur, jenis kelamin, demam, lama sakit, spesies dan jumlah parasitemia juga tidak mempunyai hubungan bermakna dengan trombistopenia.

Tabel 1. Korelasi Platelet dengan Parasitemia dan Rasio Sitokin

\begin{tabular}{lccccc}
\hline & Parasitemia & TNF $\boldsymbol{\alpha}$ & IFN $\gamma$ & IL12 & IL10 \\
\hline Platelet & $-0,369^{*}$ & $0,313^{*}$ & $0,049^{* *}$ & $-0,067^{* *}$ & $-0,335^{* *}$ \\
p sig & 0,001 & 0,006 & 0,677 & 0,563 & 0,003 \\
\hline
\end{tabular}

*Uji Pearson, **Uji Spearman 
Tabel 2. Analisis Bivariat Hubungan Trombosit dengan Variabel Independen

\begin{tabular}{|c|c|c|c|c|c|c|}
\hline & \multirow[b]{2}{*}{ Kelompok } & \multirow[b]{2}{*}{$\mathbf{n}$} & \multicolumn{2}{|c|}{ Trombosit } & \multirow[b]{2}{*}{ OR } & \multirow[b]{2}{*}{$\mathbf{p}$} \\
\hline & & & $\begin{array}{c}<150.000 / \mathrm{mm}^{3} \\
\%\end{array}$ & $\begin{array}{c}>=150.000 / \mathrm{mm}^{3} \\
\%\end{array}$ & & \\
\hline \multirow[t]{3}{*}{1} & Umur & & & & & \\
\hline & $<15$ tahun & 38 & 78,9 & 21,1 & 1,76 & 0,54 \\
\hline & $\geq 15$ tahun & 38 & 86,8 & 13,2 & & \\
\hline \multirow[t]{3}{*}{2} & Jenis Kelamin & & & & & \\
\hline & Laki - laki & 45 & 88,9 & 11,1 & 2,78 & 0,17 \\
\hline & Perempuan & 31 & 74,2 & 25,8 & & \\
\hline \multirow[t]{3}{*}{3} & Demam & & & & & \\
\hline & $<37,5^{\circ} \mathrm{C}$ & 31 & 77,8 & 22,2 & 2,67 & 0,26 \\
\hline & $\geq 37,5^{\circ} \mathrm{C}$ & 45 & 90,3 & 9,7 & & \\
\hline \multirow[t]{3}{*}{4} & Lama Sakit & & & & & \\
\hline & $<3$ hari & 28 & 78,6 & 21,4 & 1,6 & 0,66 \\
\hline & $\geq 3$ hari & 48 & 85,4 & 14,6 & & \\
\hline \multirow[t]{3}{*}{5} & Spesies & & & & & \\
\hline & P.falciparum & 39 & 57,1 & 42,9 & 4,44 & 0,053 \\
\hline & P. vivax & 37 & 23,1 & 76,9 & & \\
\hline \multirow[t]{3}{*}{6} & Parasitemia & & & & & \\
\hline & $<3.393 / \mathrm{mm}^{3}$ & 34 & 73,5 & 26,5 & 3,42 & 0,1 \\
\hline & $\geq 3.393 / \mathrm{mm}^{3}$ & 42 & 90,5 & 9,5 & & \\
\hline \multirow[t]{3}{*}{7} & Rasio TNF $\alpha /$ IL10 & & & & & \\
\hline & $<1,05$ & 38 & 94,7 & 5,3 & 7,33 & 0,015 \\
\hline & $\geq 1,05$ & 38 & 71,1 & 28,9 & & \\
\hline \multirow[t]{3}{*}{8} & Rasio IFN $\gamma /$ IL10 & & & & & \\
\hline & $<0,99$ & 38 & 89,5 & 10,5 & 2,63 & 0,22 \\
\hline & $\geq 0,99$ & 38 & 76,3 & 23,7 & & \\
\hline \multirow[t]{3}{*}{9} & Rasio IL12/IL10 & & & & & \\
\hline & $<0,99$ & 37 & 71,8 & 28,2 & 6,88 & 0,02 \\
\hline & $\geq 0,99$ & 39 & 94,6 & 5,4 & & \\
\hline
\end{tabular}

Analisis multivariat dilakukan terhadap variabel yang mempunyai nilai $\mathrm{p}<0,25$ dan yang mempunyai peran terhadap perubahan dari kadar trombosit dalam darah pada infeksi malaria. Variabel yang dianalisis adalah jenis kelamin, spesies, parasitemia dan rasio sitokin. Analisis regresi logistik dilakukan dengan menggunakan metode Forward (wald), dimana setiap variabel akan diuji dengan dimasukkan ke dalam model namun yang mempunyai nilai $\mathrm{p}>0,05$ akan dikeluarkan dari model tersebut. Hasil akhir analisis didapatkan adanya hubungan antara trombositopenia dan rasio yang rendah $(<1,05)$ dari TNF $\alpha /$ IL10 dengan adjusted OR: 7,33 $(95 \%$ CI: 1,5-35,8) dengan $p=0,014$.

\section{PEMBAHASAN}

Trombositopenia mempunyai hubungan dengan rasio TNF $\alpha /$ IL10 pada infeksi $P$. falciparum dan $P$. vivax. Hasil penelitian menunjukkan rasio rendah $(<1,05)$ dari $\mathrm{TNF} \alpha / \mathrm{IL} 10$ dapat menyebabkan kejadian 
tombositopenia 7,33 kali dibandingkan rasio $\mathrm{TNF} \alpha / \mathrm{IL} 10 \geq 1,05$. Rasio TNF $\alpha /$ IL10 yang rendah menunjukkan adanya hubungan terbalik IL10 dengan platelet. TNF $\alpha$ sebagai sitokin pro inflamasi akan diproduksi dalam tubuh untuk mengeliminasi infeksi plasmodium dan jumlahnya bervariasi bergantung dari jenis patogen, jumlah patogen, imunitas penderita dan faktor yang mempengaruhi kekebalan tubuh lainnya. Kondisi dimana $\mathrm{TNF} \alpha$ meningkat, didalilkan memicu platelet terjebak (trapping) dan digunakan untuk peradangan yang terjadi di pembuluh darah, baik pada $P$. falciparum maupun P.vivax. ${ }^{3}$ Secara in vitro, diduga platelet tersebut akan menginduksi terjadinya penggumpalan (clumping) sel darah merah yang terinfeksi $P$. falciparum pada pasien dengan malaria serebral. ${ }^{10}$ Sementara pada $P$. vivax, akan terjadi penggumpalan di sel endotel dan plasenta secara ex vivo. ${ }^{12}$ Hal ini menyebabkan peredaran platelet kurang di dalam darah (trombositopenia). Namun dengan memperhatikan uji korelasi (Tabel 1), peran TNF $\alpha$ kemungkinan secara tidak langsung terhadap kejadian trombositopenia, karena berdasarkan uji tersebut semakin banyak platelet ditemukan maka semakin banyak pula TNF $\alpha$. Produksi TNF $\alpha$ yang tinggi disebutkan akan menginduksi pelepasan sitokin proinflamasi lainnya dan berdampak pada terjadinya kerusakan jaringan sekitar infeksi. Untuk mengendalikannya diperlukan IL10, yang merupakan imunoregulator, berperan dalam mengendalikan peradangan/inflamasi kejadian infeksi di tubuh manusia. ${ }^{5}$ Kinerja IL10 dalam menghambat kerja Thelper 1 , sel NK dan makrofag akan menekan produksi sitokin pro inflamasi seperti TNF $\alpha$ dan IFN $\gamma$ serta IL12, sehingga dampak kerusakan jaringan dapat ditekan. IL10 yang terinduksi oleh karena infeksi, akan menurunkan produksi TNF $\alpha$. Namun demikian, IL10 ternyata juga akan menurunkan produksi platelet. ${ }^{3,7}$ Dalam hal ini IL10 berperan penting dan secara langsung berkaitan dengan kejadian trombositopenia pada $P$. falciparum dan $P$. vivax, sesuai dengan uji korelasi pada Tabel 1 dan hal ini konsisten dengan penelitian lainnya. ${ }^{6,7,9}$

Rasio IL12/IL10 mempunyai hubungan bermakna dengan trombositopenia. Hal ini menunjukkan IL12 juga mempunyai peran penting pada trombositopenia, hasil ini diperkuat dengan data uji korelasi (Tabel 1) yang menunjukkan adanya hubungan terbalik walaupun tidak bermakna. Hal ini konsisten dengan penelitian lainnya yang menunjukkan bahwa platelet berkorelasi negatif/terbalik dengan kadar IL12. ${ }^{9}$ IL12 sebagai sitokin pro inflamasi, akan memicu kerja sitokin pro inflamasi lainnya seperti TNF $\alpha$ dan IFN $\gamma$ untuk menghadapi infeksi malaria. Proses ini tentunya akan menginduksi IL10 yang berperan dalam proses pengendalian dampak respon sitokin pro inflamasi dan meningkatkan kejadian trombositopenia $(\mathrm{OR}=6,88, \mathrm{p}=0,02)$. Analisis bivariat lainnya menunjukkan jenis spesies dan parasitemia tidak ada hubungan yang bermakna dengan trombositopenia. Kemungkinannya berkaitan dengan cara kerja spesies dan lamanya parasitemia dalam tubuh penderita.

Pada penelitian ini, trombositopenia terjadi pada $82,9 \%$ kasus dan tidak berbeda bermakna antara $P$. falciparum dan $P$. vivax. Hal ini konsisten dengan penelitian lainnya yang dilakukan di India. ${ }^{13-15}$ Cara kerja P. falciparum dan P.vivax dikaitkan denganjenisseldarah merah yang terinfeksi dan mekanisme patofosiologi berbeda, berdasarkan hal ini seharusnya ada perbedaan kejadian trombositopenia. Namun demikian, insiden tombositopenia sama antara kedua spesies tersebut. ${ }^{13}$ Sementara berkaitan dengan parasitemia, ditunjukkan kejadian trombositopenia lebih banyak terjadi pada kelompok parasitemia $\geq 3.393 / \mathrm{mm}^{3}$. Seperti disebutkan sebelumnya, platelet berkaitan dengan proses penggumpalan sel darah merah yang terinfeksi, konsekuensinya semakin banyak sel darah merah terinfeksi, maka semakin banyak platelet digunakan. ${ }^{2}$ Jika terjadi dalam waktu lama tentunya akan memicu terjadinya trombositopenia berat (platelet $<50000$ / $\mathrm{mm}^{3}$ ). Dengan kata lain, semakin banyak dan lama parasitemia berada dalam tubuh maka akan berpengaruh pada berat ringannya trombositopenia. Hal ini didukung hasil uji korelasi (Tabel. 1) yang menunjukkan semakin banyak parasit dalam tubuh maka jumlah platelet akan semakin berkurang $(\mathrm{p}=0,001)$. Namun demikian, hal tersebut tidak ditemukan 
bermakna pada pengelompokan parasitemia. Fase akut ( $\leq 7$ hari ) kemungkinan berperan menunjukkan ketidakberbedaan bermakna kejadian pengelompokan trombositopenia dan parasitemia pada penelitian ini.

IFN $\gamma$ merupakan sitokin yang berperan dalam mengendalikan perkembangan infeksi plasmodium, produksinya diinduksi oleh IL12. ${ }^{16}$ Sitokin ini akan melakukan proses fagositosis plasmodium dan menginduksi produksi sitokin lainnya termasuk $\mathrm{TNF} \alpha$ yang berperan pada trombositopenia. Hal ini menunjukkan bahwa IFN lebih berperan pada menekan infeksi malaria dibandingkan menyebabkan trombositopenia. Hasil penelitian ini menunjukkan baik pada uji korelasi, bivariat dan multivariate, IFN tidak berhubungan dengan trombositopenia. Hasil ini konsisten dengan penelitian di Korea Selatan yang tidak mendapatkan adanya perbedaan IFN antara pasien dengan atau tanpa trombositopenia. ${ }^{17}$

Trombositopenia merupakan gejala laboratoris yang sering ditemukan pada infeksi malaria baik pada $P$. falciparum dan $P$. vivax. Pada penelitian ini, kejadian trombositopenia sudah terjadi dalam 1-7 hari setelah sakit. Hasil penelitian lainnya menunjukkan bahwa kejadian penurunan platelet bahkan sudah terjadi setelah 7-9 hari setelah digigit oleh nyamuk terinfeksi. ${ }^{18}$ Perubahan hematologi ini sudah sering dilaporkan pada berbagai penelitian. ${ }^{2,14,15,19}$ Bahkan sudah ada yang menyatakan bahwa trombositopenia dapat digunakan sebagai salah satu penanda adanya infeksi malaria. ${ }^{20,21}$ Gambaran trombositopenia ini menjadi penting terutama pada daerah endemis malaria. Hal ini dapat memicu perdarahan dalam tubuh ${ }^{19}$ dan bermanifestasi pada berat ringannya malaria. Gambaran trombositopenia dalam penelitian ini berkaitan dengan aktivitas rasio sitokin TNF $\alpha /$ IL10 $(p=0,014)$. Sitokin dapat memicu berbagai manifestasi klinis dan laboratoris dalam tubuh dan trombositopenia dapat menjadi salah satu gambaran khas yang dapat digunakan menilai berat ringannya malaria dalam tubuh. ${ }^{22}$ Oleh karenanya, pemeriksaan trombositopenia dapat digunakan pada fasilitas kesehatan primer seperti puskesmas.

Keterbatasan dari tulisan ini adalah jumlah sampel yang minimal dan keterbatasan suku yang diperiksa. Tulisan ini merupakan bagian dari penelitian utama yaitu "Hubungan kadar hemoglobin dengan respon sitokin pro inflamasi dan anti inflamasi pada penderita infeksi $P$. falciparum dan $P$. vivax" di Timika Tahun 2010. Hal ini menyebabkan jumlah sampel yang dinilai hanya berasal dari penelitian tersebut. Namun demikian, hasil masih bisa digunakan walaupun membutuhkan jumlah sampel lebih besar untuk bisa menilai gambaran trombositopenia dihubungkan dengan sitokin lainnya seperti IFN $\gamma$. Penelitian hanya dilakukan di Timika dan daerah endemis tinggi malaria. Respon imun sangat bervariasi dan diantaranya dipengaruhi oleh suku dan daerah infeksi. Hasil penelitian ini masih menggambarkan respon imun pada daerah endemis tinggi, belum mencakup daerah endemis lainnya. Namun demikian, hasil ini cukup menjelaskan hubungan trombositopenia dan sitokin sebagai dasar untuk penelitian lebih lanjut.

\section{KESIMPULAN}

Trombositopenia dikaitkan dengan rendahnya rasio TNF $\alpha /$ IL10 pada pasien infeksi dari P. falciparum dan $P$. vivax tanpa komplikasi.

\section{SARAN}

Berdasarkan penelitian tersebut di atas, pemeriksaan trombositopenia dapat dilakukan sebagai suatu penanda adanya infeksi malaria terutama pada daerah endemis malaria. Namun demikian tetap diperlukan uji sensitivitas dan spesifisitas dalam penggunaannya karena trombositopenia juga terjadi pada beberapa infeksi dan penyebab lainnya. Selain itu kejadian trombositopenia yang berkaitan dengan sitokin tidak berdiri sendiri sehingga diperlukan penelitian lebih lanjut dalam menilai faktor yang berpengaruh pada trombositopenia akibat malaria.

\section{UCAPAN TERIMA KASIH}

Kami berterima kasih kepada seluruh pihak yang telah membantu pelaksanaan penelitian ini yaitu seluruh subyek penelitian dan tim penelitian di RS Mitra Masyarakat Timika serta tim laboratorium Badan Litbangkes. 


\section{DAFTAR PUSTAKA}

1. Sekhon SS, Roy V. Thrombocytopenia in adults: a practical approach to evaluation and management. Southern Medical Journal. 2006;99(5):491.

2. Lacerda MVG, Mourão MPG, Coelho HCC, Santos JB. Thrombocytopenia in malaria: who cares? Memorias do Instituto Oswaldo Cruz. 2011;106:52-63.

3. Angulo I, Fresno M. Cytokines in the pathogenesis of and protection against malaria. Clinical and diagnostic laboratory immunology. 2002;9(6):1145-52.

4. Rodrigues-da-Silva RN, Lima-Junior JdC, Antas PRZ, Baldez A, Storer FL, Santos $\mathrm{F}$, et al. Alterations in cytokines and haematological parameters during the acute and convalescent phases of Plasmodium falciparum and Plasmodium vivax infections. Memorias do Instituto Oswaldo Cruz. 2014;109(2):154-62.

5. Couper KN, Blount DG, Riley EM. IL10: the master regulator of immunity to infection. The Journal of Immunology. 2008;180(9):5771-7.

6. Casals-Pascual C, Kai O, Newton CR, Peshu N, Roberts DJ. Thrombocytopenia in falciparum malaria is associated with high concentrations of IL-10. The American journal of tropical medicine and hygiene. 2006;75(3):434-6.

7. Raza A, Khan MS, Ghanchi NK, Raheem A, Beg MA. Tumour necrosis factor, interleukin-6 and interleukin-10 are possibly involved in Plasmodium vivax-associated thrombocytopaenia in southern Pakistani population. Malaria journal. 2014;13(1):323.

8. Hanisch BR, Bangirana P, Opoka RO, Park GS, John CC. Thrombocytopenia May Mediate Disease Severity in Plasmodium falciparum Malaria Through Reduced Transforming Growth Factor Beta-1 Regulation of Proinflammatory and Antiinflammatory Cytokines. The Pediatric infectious disease journal. 2015;34(7):783-8.

9. Goncalves RM, Scopel KK, Bastos MS, Ferreira MU. Cytokine balance in human malaria: does Plasmodium vivax elicit more inflammatory responses than Plasmodium falciparum? PLoS One. 2012;7(9):e44394.

10. Wassmer SC, Taylor T, MacLennan CA,
Kanjala M, Mukaka M, Molyneux ME, et al. Platelet-induced clumping of Plasmodium falciparum-infected erythrocytes from Malawian patients with cerebral malariapossible modulation in vivo by thrombocytopenia. Journal of Infectious Diseases. 2008;197(1):72-8.

11. Hasugian AR, Wibowo H, Tjitra E. Hubungan kadar hemoglobin dengan respon sitokin proinflamasi dan antiinflamasi pada penderita infeksi Plasmodium falciparum dan Plasmodium vivax di Timika, Papua tahun 2010. Media Litbang Kesehatan. 2012;1:6-17.

12. Carvalho BO, Lopes SC, Nogueira PA, Orlandi PP, Bargieri DY, Blanco YC, et al. On the cytoadhesion of Plasmodium vivaxinfected erythrocytes. Journal of Infectious Diseases. 2010;202(4):638-47.

13. Saravu K, Docherla M, Vasudev A, Shastry B. Thrombocytopenia in vivax and falciparum malaria: an observational study of 131 patients in Karnataka, India. Annals of Tropical Medicine \& Parasitology. 2011;105(8):593-8.

14. Gupta NK, Bansal SB, Jain UC, Sahare K. Study of thrombocytopenia in patients of malaria. Tropical parasitology. 2013;3(1):58.

15. Shaikh QH, Ahmad SM, Abbasi A, Malik SA, Sahito AA, Munir S. Thrombocytopenia in malaria. J Coll Physicians Surg Pak. 2009;19(11):708-10.

16. Artavanis-Tsakonas K, Riley EM. Innate Immune Response to Malaria: Rapid induction of IFN-y from Human NK Cells by Live Plasmodium falciparum-infected Erythrocytes. J Immunol. 2002;169:295663.

17. Park J-W, Park S-H, Yeom J-S, Huh A-J, Cho Y-K, Ahn J-Y, et al. Serumc ytokine pro $\square$ les in patients with Plasmodium vivax malaria : a comparison between those who presented with and without thrombocytopenia. AnnalsofTropicalMedicine\&Parasitology ,Vo197,No4,339-344(2003). 2003.

18. de Mast Q, Groot E, Lenting PJ, de Groot PG, McCall M, Sauerwein RW, et al. Thrombocytopenia and release of activated von Willebrand Factor during early Plasmodium falciparum malaria. Journal of Infectious Diseases. 2007;196(4):622-8. 
19. Muley A, Lakhani J, Bhirud S, Patel A. Thrombocytopenia in Plasmodium vivax malaria: How significant? Journal of tropical medicine. 2014;2014.

20. Khan SJ, Abbass Y, Marwat MA. Thrombocytopenia as an indicator of malaria in adult population. Malaria research and treatment. 2012;2012.
21. Arshad AR. Thrombocytopenia in malaria: can platelet counts differentiate malaria from other infections? Journal of the College of Physicians and Surgeons Pakistan. 2015;25(1):31-4.

22. Jadhav U, Patkar V, Kadam N. Thrombocytopenia in malaria-correlation with type and severity of malaria. JAPI. 2004;52(615):8. 